\title{
Induction of mast cell accumulation, histamine release and skin edema by $\mathbf{N} 49$ phospholipase $\mathrm{A}_{2}$ Ji-Fu Wei ${ }^{1,2}$, Xiao-Long Wei ${ }^{2}$, Ya-Zhen $\mathrm{Mo}^{2}$ and Shao-Heng $\mathrm{He}^{* 1,2}$
}

Address: ${ }^{1}$ Clinical Experiment Center, the First Affiliated Hospital of Nanjing Medical University, Nanjing, 210029, PR China and ${ }^{2}$ Allergy and Inflammation Research Institute, the Shantou University Medical College, Shantou, Guangdong, 515041, PR China

Email: Ji-Fu Wei - weijifu@hotmail.com; Xiao-Long Wei - g_xlwei@stu.edu.cn; Ya-Zhen Mo - g_yzmo@stu.edu.cn; ShaoHeng He* - shoahenghe@hotmail.com

* Corresponding author

Published: 28 April 2009

BMC Immunology 2009, 10:21 doi:10.1|86/147|-2172-10-21
Received: I December 2008

Accepted: 28 April 2009

This article is available from: http://www.biomedcentral.com/I47|-2/72/I0/2I

(c) 2009 Wei et al; licensee BioMed Central Ltd.

This is an Open Access article distributed under the terms of the Creative Commons Attribution License (http://creativecommons.org/licenses/by/2.0), which permits unrestricted use, distribution, and reproduction in any medium, provided the original work is properly cited.

\begin{abstract}
Background: It has been recognized that phospholipase $A_{2}\left(P L A_{2}\right)$ is a crucial component of snake venom, which contributes greatly to snake venom induced inflammation in man. However, the mechanisms through which N49 PLA ${ }_{2}$ provoke inflammation remain unclear. Recently, a N49 PLA, TM-N49 from Protobothrops mucrosquamatus crude venom was characterized in our laboratory. Since the purification procedure developed is able to supply us with relatively large quantity of highly purified TM-N49, we investigated the ability of TM-N49 in induction of inflammation.

Results: The results showed that TM-N49 provoked a dose dependent increase in microvascular leakage in the skin of rats. The potency of TM-N49 in induction of skin edema appeared similar potency of bradykinin and histamine. Pretreatment of rats with compound 48/80 diminished TMN49 induced skin reaction and reduced mast cell numbers in rats. Ginkgolide B and cyproheptadine, but not terfenadine and quinacrine, inhibited TM-N49 elicited microvascular leakage when they were co-injected with the stimulus to rat skin. Moreover, TM-N49 was found to induce histamine release from human colon, lung and tonsil mast cells, and both metabolic inhibitors and pertussis toxin were capable of inhibiting TM-N49 elicited histamine release. TMN49 induced mast cell accumulation in the peritoneum of mice, which was inhibited by co-injection of ginkgolide B, cyproheptadine and terfenadine. Intravenous injection of monoclonal antibodies against CDI8, ICAM-I and CDI la also blocked TM-N49 induced mast cell accumulation.
\end{abstract}

Conclusion: TM-N49 is a potent stimulus for skin edema, mast cell activation and accumulation.

\section{Background}

Snake venoms are chemically complex mixtures of pharmacologically active proteins or peptides, which serve not only as a source of digestive enzymes, but also play an important role in immobilizing the prey and acting as offensive weapons. They can target multiple tissues, causing simultaneous damage of multiple physiological systems. One of the components which contribute significantly to the lethality of snake venoms is phospholipase $\mathrm{A}_{2}\left(\mathrm{PLA}_{2}\right)$ (EC 3.1.1.4) [1]. PLA 2 constitutes a family of structurally related proteins hydrolyze phospholipids at the sn-2 position in a calcium-dependent manner, releasing fatty acids and lysophospholipids [2]. Snake venom $\mathrm{PLA}_{2} \mathrm{~s}$ are low-molecular weight $(13,000-14,000$ Da), secretory phospholipases containing seven disulfide bonds. Based on their amino acid sequence and disulfide 
bond pattern, snake venom $\mathrm{PLA}_{2} \mathrm{~s}$ are classified into group I $\mathrm{PLA}_{2}$ (from Elapidae/Hydrophidae) or group II $\mathrm{PLA}_{2}$ (from Crotalidae/Viperidae) [3]. Usually, the group II $\mathrm{PLA}_{2} \mathrm{~s}$ are further subdivided into two major subgroups: the Asp-49 PLA $_{2}$ s (D49 PLA $_{2}$ s), which have an aspartic acid at position 49 and high catalytic activity towards artificial phospholipid substrates; and Lys-49 PLA $_{2}$ s (K49 $\mathrm{PLA}_{2} \mathrm{~s}$ ), which have a lysine substitutes at position 49 and very low or no hydrolytic activity towards artificial phospholipid substrates $[4,5]$. Recently, a unique subgroup of snake venom group II PLA ${ }_{2}$, named N49 PLA 2 subgroup was identified from several Asiatic snake venoms [6-8]. The N49 PLA 2 was found to differ from the other subgroups in its structure and biological activities.

Besides the digestive function, snake $\mathrm{PLA}_{2} \mathrm{~s}$ exhibit severalother pharmacological properties including antiplatelet $[9,10]$, anticoagulant [11], hemolytic [9], neurotoxic (presynaptic) [12], myotoxic [13-15]. They have also been employed widely as pharmacological tools to investigate the roles of these enzymes in diverse models of experimental inflammatory processes such as edema, inflammatory cell infiltration and mast cells activation [15-20]. Mast cells are primarily located in mucosal and perivascular areas of various tissues, which play an important role in body defense processes. Recent studies found that mast cells can be activated by snake venom and release carboxypeptidase A and possibly other proteases, which can degrade venom components $[21,22]$. Our former study also showed that atrahagin, a metalloprotienase purified from Naja atra snake, could potently activate human colon, lung and tonsil mast cells to release histamine [23]. Several snake venom $\mathrm{PLA}_{2} \mathrm{~s}$ were reported to be able to activate the rat mast cells, to induce microvascular leakage and inflammatory cell accumulation at the sites of inflammation [15-20]. However, little is known of the action of N49 $\mathrm{PLA}_{2}$ s on human mast cells, and the mechanisms through which $\mathrm{N}_{4} 9 \mathrm{PLA}_{2}$ induces microvascular leakage and inflammatory cell accumulation still remain obscure. Therefore, we investigated the mechanisms of TM-N49 [6] in induction of microvascular leakage and mast cell accumulation and activation in the present study.

\section{Results \\ Purification and characterization of TM-N49}

Approximately $15 \mathrm{mg}$ of TM-N49 was obtained from 1.5 $\mathrm{g}$ Protobothrops mucrosquamatus crude venom following the procedures described above. The purity of the $\mathrm{PLA}_{2}$ was at least $98 \%$ as assessed by SDS-PAGE, HPLC and mass spectrometry analysis.

\section{Induction of microvascular leakage by TM-N49}

TM-N49 at doses of 0.15-5.0 $\mu \mathrm{g}$ provoked a dose dependent increase in microvascular leakage in the skin of rats at $20 \mathrm{~min}$ following injection. As little as $0.15 \mu \mathrm{g}$ was able to stimulate significant skin edema after injection indicating that TM-N49 is a potent stimulus. The potency of TM-N49 in induction of skin edema is similar to that of bradykinin and histamine on the weight basis (all at $5 \mu \mathrm{g}$ ) (Figure 1). Pretreatment of rats with compound $48 / 80$ for a period longer than $72 \mathrm{~h}$ clearly diminished the skin responsiveness of the rats to TM-N49 and histamine (Figure 2A), and dramatically reduced mast cell numbers in the peritoneal lavage fluid of these rats (Figure 2B).

\section{Influence of anti-inflammatory compounds on microvascular leakage}

Ginkgolide B at a dose of $5 \mu \mathrm{g}$ inhibited 73.5\%, 77.5\% and $40 \%$ microvascular leakage induced by PAF, histamine and TM-N49, respectively when it was co-injected with these stimuli. Cyproheptadine at a dose of $5 \mu \mathrm{g}$ also inhibited $85.6 \%$ and $94.7 \%$ histamine and TM-N49 elicited microvascular leakage. Terfenadine and quinacrine at the dose of $5 \mu \mathrm{g}$ had little effect on TM-N49 provoked microvascular leakage in rat skin (Figure 3). All antiinflammatory compounds tested by themselves had no significant effect on the microvascular leakage in rat skin (data not shown).

\section{Induction of histamine release from mast cells by TM-N49} A dose dependent release of histamine from colon, lung and tonsil mast cells was observed when various concentrations of TM-N49 were incubated with cells for $15 \mathrm{~min}$. As low as $0.03 \mu \mathrm{g} / \mathrm{ml}$ of TM-N49 was able to stimulate significant histamine release from human colon and lung mast cells, but to stimulate a similar level of histamine release from tonsil mast cells a minimum of $3.0 \mu \mathrm{g} / \mathrm{ml}$ of TM-N49 was required. While TM-N49 at a concentration of $30 \mu \mathrm{g} / \mathrm{ml}$ was able to provoke approximately $30 \%, 15 \%$ and $62 \%$ net histamine release, anti-IgE antibody at a concentration of $10 \mu \mathrm{g} / \mathrm{ml}$ stimulated approximately $17 \%$, $17 \%$ and $11 \%$ net histamine release from colon, lung and tonsil mast cells, respectively in the parallel experiments. At a concentration of $30 \mu \mathrm{g} / \mathrm{ml}$, TM-N49 induced also significant histamine release from colon and tonsil mast cells when calcium and magnesium were absent in the challenge buffer (Figure 4).

\section{Time course for TM-N49 induced histamine release}

Immediately after adding $30 \mu \mathrm{g} / \mathrm{ml}$ of TM-N49 to cells, histamine release from colon, lung and tonsil mast cells occurred. Approximately $26.8 \%, 26.1 \%$ and $44.1 \%$ of the maximum of histamine release were observed following incubation of TM-N49 with colon, lung and tonsil cells, respectively for $1 \mathrm{~min}$. At the same time point, anti-IgE antibody at $10 \mu \mathrm{g} / \mathrm{ml}$ induced $12.5 \%, 26.2 \%$ and $34.3 \%$ of the maximum of histamine release, and calcium ionophore at a concentration of $1 \mu \mathrm{g} / \mathrm{ml}$ provoked $34.7 \%$, $58.1 \%$ and $44.1 \%$ of the maximum of histamine release 


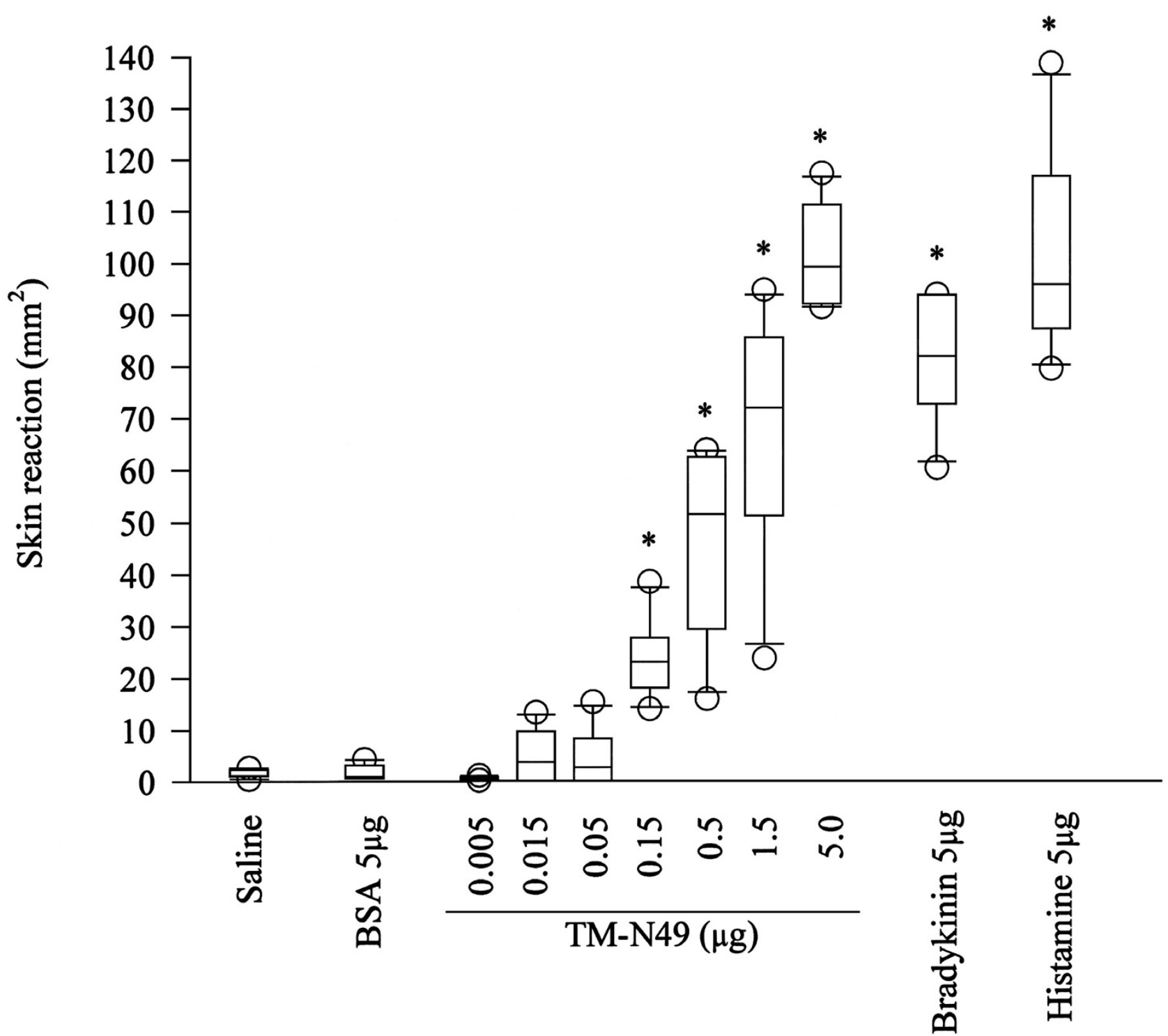

Figure I

Effect of TM-N49 on rat dermal microvascular leakage. Various doses of TM-N49 were injected into the skin of rat for $20 \mathrm{~min}$. Also shown are the responses to BSA, bradykinin and histamine alone at a dose of $5 \mu \mathrm{g}$ and normal saline control. Skin reaction represented the area of Evan's blue extravasation. Data are displayed as a boxplot, which indicates the median, interquartile range, the largest and smallest values other than outliers $(O)$ (defined as those which are more than I.5 box lengths from the median) for 6 animals in each group. $* P<0.05$ compared with the response to the diluent only control animals.

from colon, lung and tonsil mast cells, respectively (Figure $5)$.

The peak of histamine released from colon, tonsil and lung mast cells in response to TM-N49 occurred at 10, 10 and 8 min following TM-N49 being added to cells, whereas in the parallel experiments, the peak histamine release induced by anti-IgE antibody occurred at 7, 10 and 7 min for colon, lung and tonsil mast cells, respectively.
Similarly, the peak histamine release provoked by calcium ionophore appeared at 6, 7 and $8 \mathrm{~min}$ for colon, lung and tonsil mast cells, respectively. The maximum release of histamine was then sustained at least to $20 \mathrm{~min}$ (Figure 5).

\section{Effects of metabolic inhibitors and pertussis toxin on histamine release}

When cells were pretreated with metabolic inhibitors for $40 \mathrm{~min} 3 \mu \mathrm{g} / \mathrm{ml}$ of TM-N49 induced histamine release 

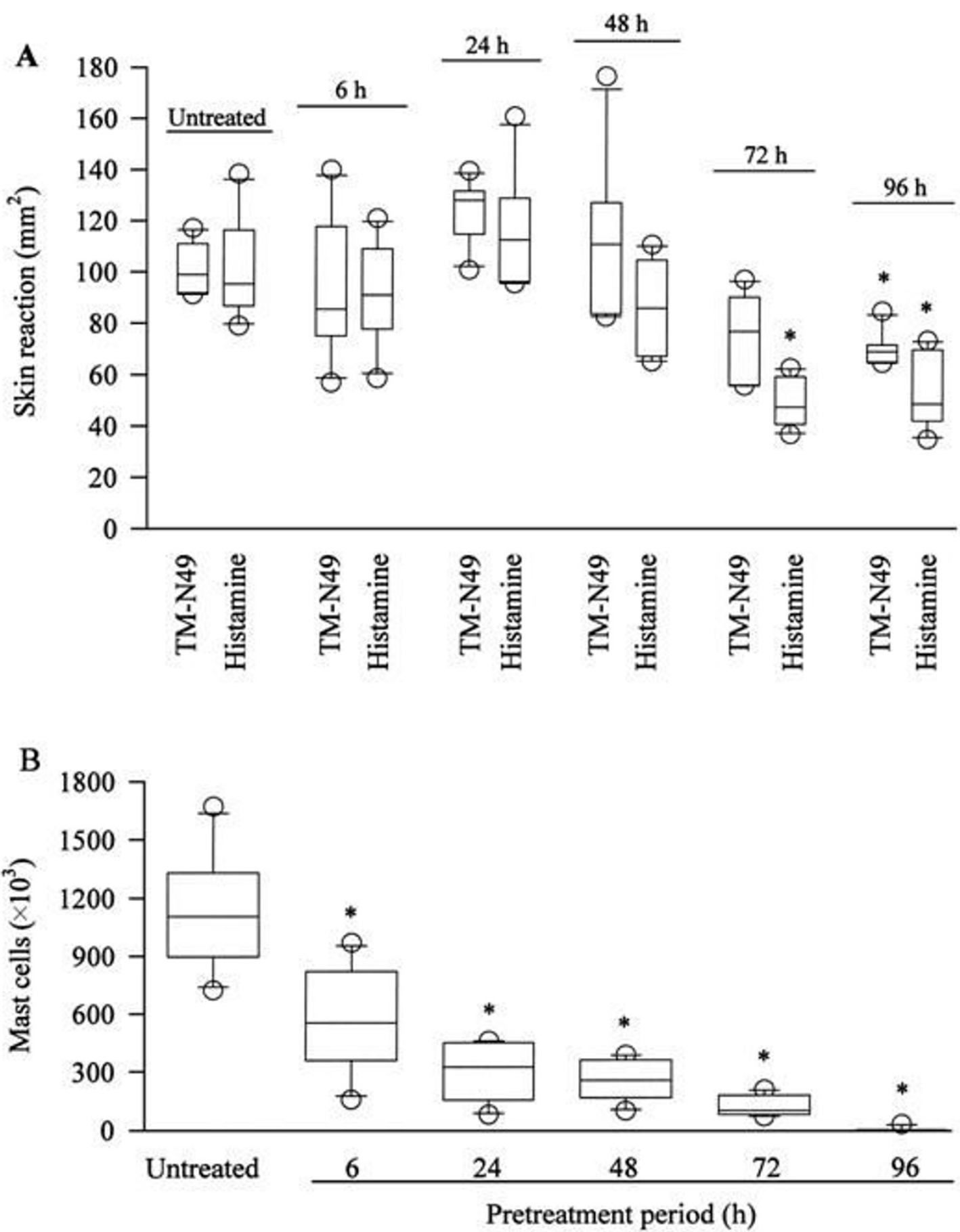

Figure 2

Influence of compound $48 / 80$ on rat dermal microvascular leakage induced by TM-N49 and histamine (A), and on mast cell numbers in the peritoneum of rats (B). Rats were intra-peritoneally injected with compound $48 / 80$ at a dose of $0.6 \mathrm{mg} \cdot \mathrm{kg}^{-1}$ for $6 \mathrm{~h}$, twice a day for 3 days, and doubled dose in day 4 before TM-N49 (5 $\left.\mu \mathrm{g}\right)$ or histamine (5 $\left.\mu \mathrm{g}\right)$ being administrated for $20 \mathrm{~min}$. Skin reaction represented the area of Evan's blue extravasation. Data are displayed as a boxplot, which indicates the median, interquartile range, the largest and smallest values other than outliers (O) (defined as those which are more than 1.5 box lengths from the median) for 6 animals in each group. In $(\mathbf{A}), * P<0.05$ compared with the corresponding response to untreated animals and in $(\mathbf{B}), * P<0.05$ compared with the response to untreated animals. 


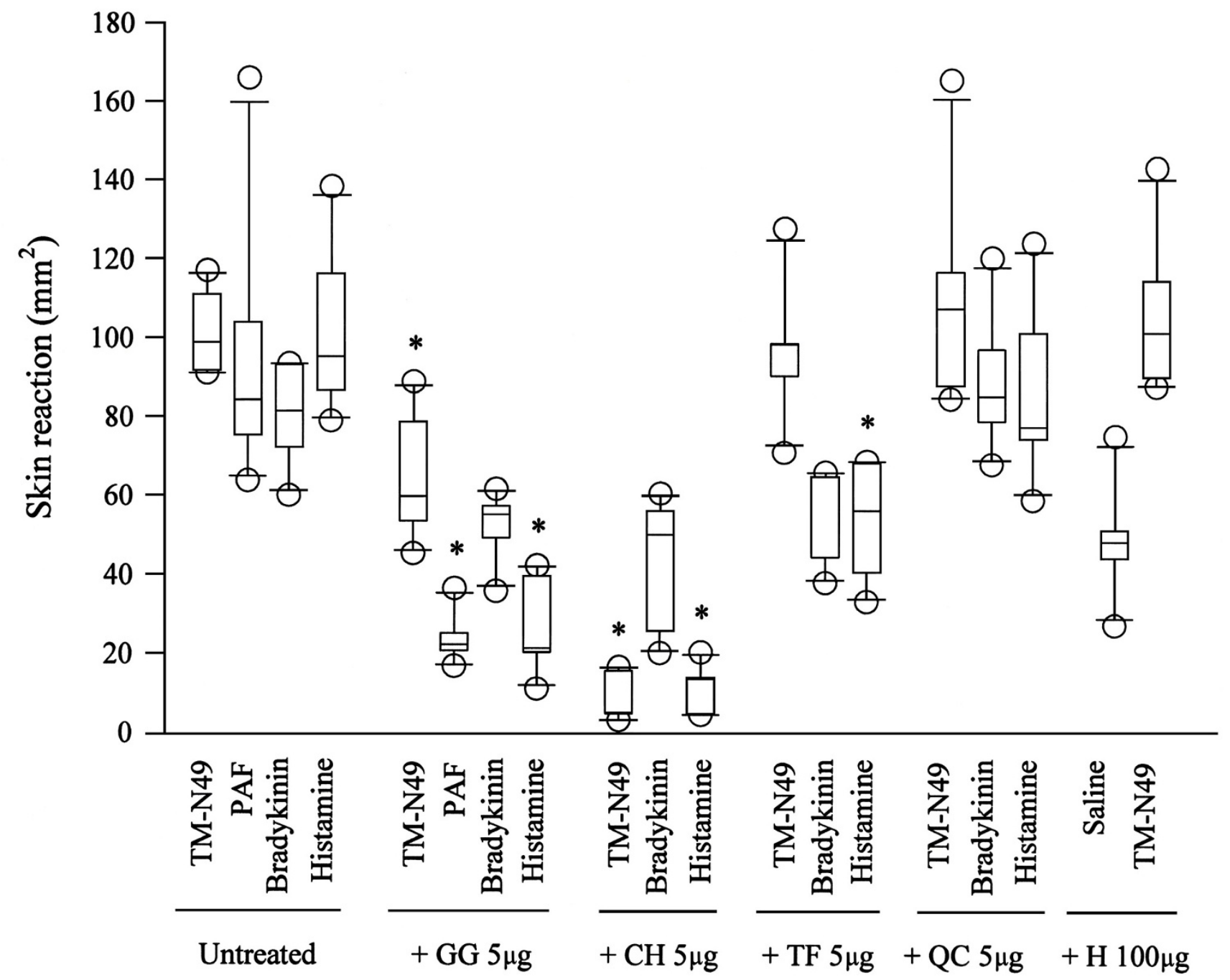

Figure 3

Influence of anti-inflammatory drugs on rat dermal microvascular leakage induced by TM-N49 (5 $\mu \mathrm{g})$, bradykinin $(5 \mu \mathrm{g})$, PAF (5 $\mu \mathrm{g})$ and histamine (5 $\mu \mathrm{g})$. Ginkgolide (GG, $5 \mu \mathrm{g})$, cyproheptadine $(\mathrm{CH}, 5 \mu \mathrm{g})$, terfenadine (TF, $5 \mu \mathrm{g})$ or quinacrine (QC, $5 \mu \mathrm{g}$ ) were co-injected with TM-N49, bradykinin or histamine, respectively for 20 min, whereas PAF was only co-injected with GG. Skin reaction represented the area of Evan's blue extravasation. Data are displayed as a boxplot, which indicates the median, interquartile range, the largest and smallest values other than outliers $(O)$ (defined as those which are more than $\mathrm{I} .5$ box lengths from the median) for 6 animals in each group. $* P<0.05$ compared with the response to the corresponding uninhibited control animals.

from colon, lung and tonsil mast cells was completely abolished. However, metabolic inhibitors exhibited little effect on histamine release from tonsil mast cells when 30 $\mu \mathrm{g} / \mathrm{ml}$ of TM-N49 was added to cells. Similarly, metabolic inhibitors dramatically inhibited anti-IgE antibody provoked histamine release from colon, lung and tonsil mast cells, but had relatively less efficient inhibition of calcium ionophore elicited histamine release from mast cells (Table 1). Pretreatment of cells with pertussis toxin for 4 $h$ reduced dramatically their responses to TM-N49 and
anti-IgE antibody, but had no significant effect on their ability to release histamine in response to calcium ionophore (Table 2).

\section{Induction of mast cell accumulation by TM-N49}

As early as $10 \mathrm{~min}$ following injection, $5 \mu \mathrm{g}$ of TM-N49 was able to induce significant mast cell accumulation in the peritoneum of mice. The mast cell accumulation induced by TM-N49 appeared to at least maintain for 16 h. As little as $0.5 \mu \mathrm{g}$ of TM-N49 was able to potently 


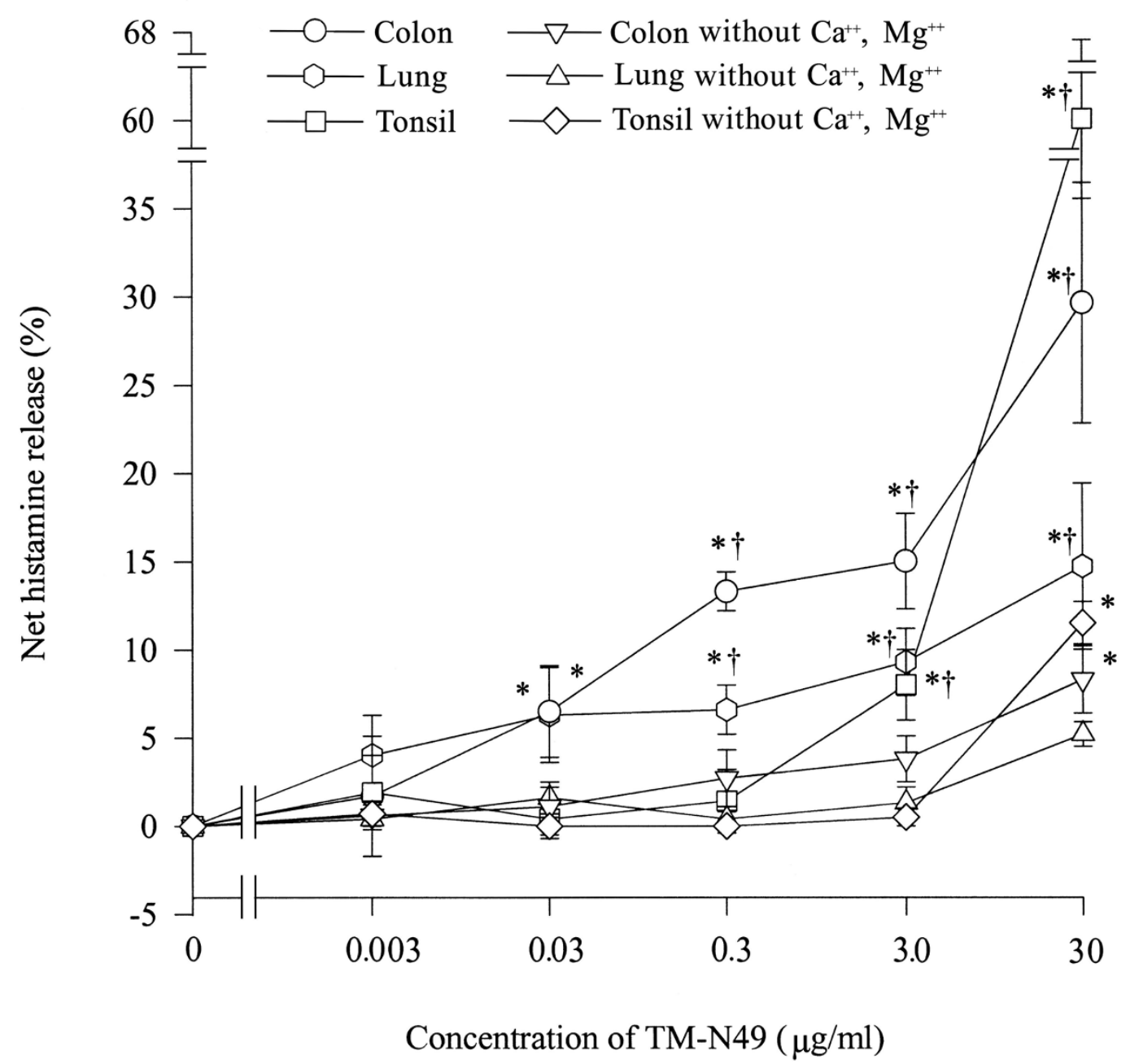

\section{Figure 4}

Effects of TM-N49 on histamine release from colon, lung and tonsil mast cells in the presence or absence of exogenous calcium and magnesium. The values shown are mean \pm SE for four to five separate experiments. Various concentrations of TM-N49 were incubated with cells for 15 min before termination of the reactions. $* P<0.05$ compared with the response to the corresponding buffer alone group, $\uparrow P<0.05$ compared with the response to the corresponding group in the absence of calcium and magnesium.

induce mast cell infiltration in the peritoneum of mice at $6 \mathrm{~h}$ and $16 \mathrm{~h}$ following injection (Figure 6). However, relative mast cell number in mouse peritoneum was not significantly increased except for $5 \mu \mathrm{g}$ of TM-N49 injected for $2 \mathrm{~h}$. At $50 \mu \mathrm{g}$, TM-N49 markedly reduced relative number of mast cells at all the time points examined following injection (Table 3).

\section{Effects of anti-inflammatory compounds and blocking} antibodies on mast cell accumulation

When co-injected, ginkgolide $\mathrm{B}$, cyproheptadine and terfenadine inhibited $85.6 \%, 80 \%$ and $100 \%$ TM-N49 induced mast cell accumulation in the peritoneum of mice, respectively. However, quinacrine did not significantly alter the extent of TM-N49 induced mast cell accumulation. At the dose tested, ginkgolide $B$, cyproheptadine, terfenadine and quinacrine by themselves failed to induce mast cell accumulation in the peritoneum of mice (Table 4).

Intravenous injection of monoclonal antibodies against CD18, ICAM-1 and CD11a 30 min prior to intra-peritoneal injection of the PLA2 blocked TM-N49 induced mast cell accumulation by $70 \%$ and $99 \%$, respectively. Monoclonal antibodies against L-selectin failed to diminish TM$\mathrm{N} 49$ induced mast cell accumulation in the peritoneum of 

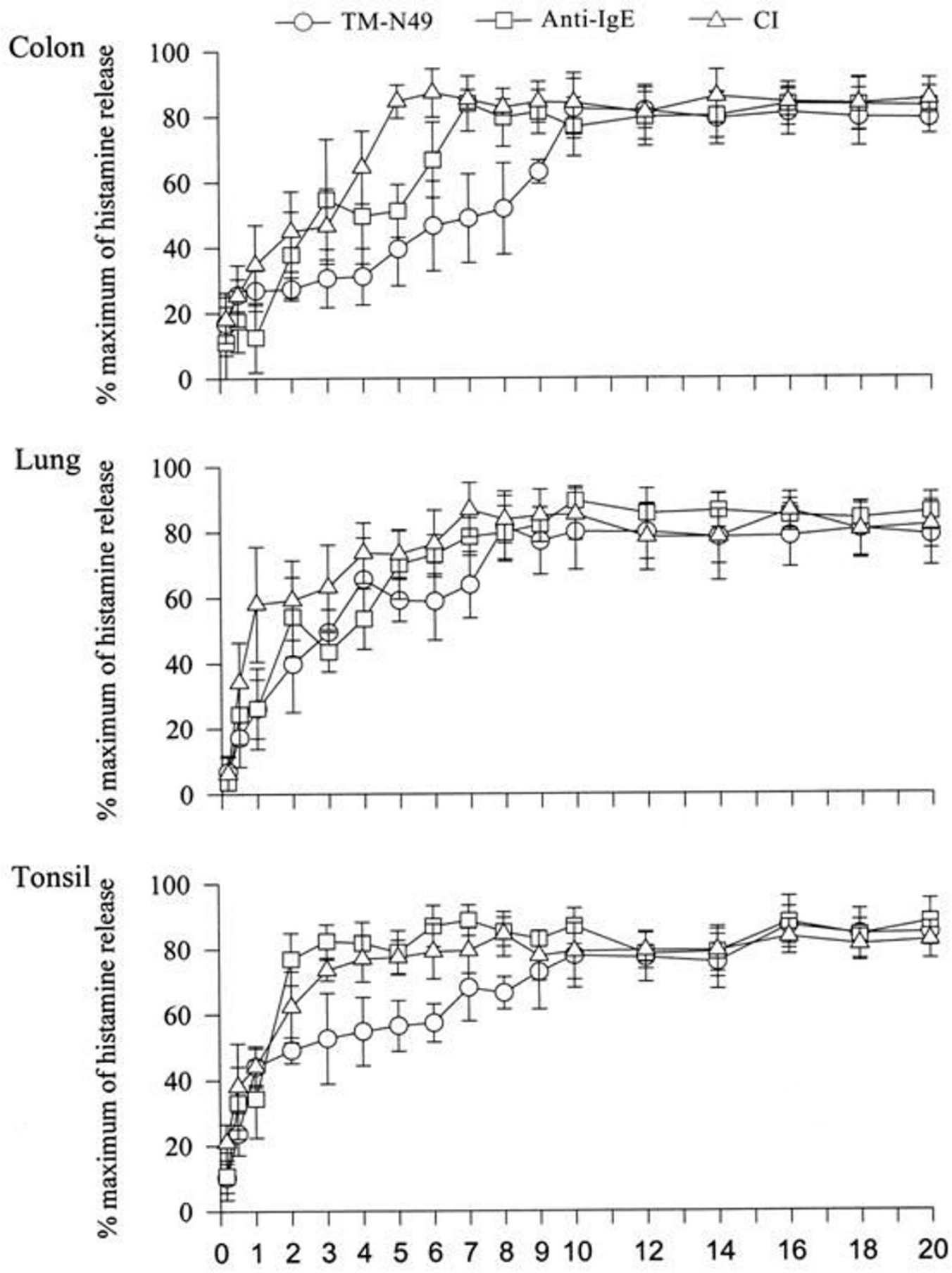

Time (min)

\section{Figure 5}

Time course for histamine release from colon, lung and tonsil mast cells induced by TM-N49 (30 $\mu \mathrm{g} / \mathrm{ml})$, antiIgE antibody $(10 \mu \mathrm{g} / \mathrm{ml})$ and calcium ionophore $(\mathrm{I} \mu \mathrm{g} / \mathrm{ml})$. The values shown are mean \pm SE of the percentage of maximum histamine release, which equals (actual net histamine release/maximum net histamine release induced by the testing compound) $\times 100 \%$, for four to five separate experiments. 
Table I: The effect of metabolic inhibitors on TM-N49 induced histamine release from human mast cells

\begin{tabular}{|c|c|c|c|c|c|c|c|}
\hline \multirow{3}{*}{$\begin{array}{l}\text { Compound } \\
(\mu \mathrm{g} / \mathrm{ml})\end{array}$} & & \multicolumn{6}{|c|}{ Net histamine release (\%) } \\
\hline & & \multicolumn{3}{|c|}{ Without metabolic inhibitors } & \multicolumn{3}{|c|}{ With metabolic inhibitors } \\
\hline & & Lung & Colon & Tonsil & Lung & Colon & Tonsil \\
\hline \multirow[t]{2}{*}{ TM-N49 } & 3.0 & $9.3 \pm 1.9$ & $13.5 \pm 3.0$ & $8.0 \pm 2.0$ & $0.4 \pm 0.4^{*}$ & $0.4 \pm 0.7^{*}$ & $0.8 \pm 0.6^{*}$ \\
\hline & 30 & $14.7 \pm 4.7$ & $29.6 \pm 6.8$ & $62.0 \pm 8.5$ & $1.6 \pm 0.9 *$ & $0.4 \pm 1.4^{*}$ & $49.3 \pm 7.5$ \\
\hline Anti-lgE & 10 & $17.3 \pm 5.4$ & $17.4 \pm 5.1$ & $11.1 \pm 3.4$ & $0.7 \pm 1.7^{*}$ & $0.1 \pm 0.8^{*}$ & $2.2 \pm 1.5^{*}$ \\
\hline $\mathrm{Cl}$ & 0.5 & $24.4 \pm 6.3$ & $38.8 \pm 4.6$ & $37 \pm 9.3$ & $5.3 \pm 5.5^{*}$ & $2.1 \pm 0.7^{*}$ & $6.4 \pm 2.9 *$ \\
\hline
\end{tabular}

The values shown are mean $\pm \mathrm{SE}$ for four to five separate experiments performed in duplicate. Cells were incubated with metabolic inhibitors 2 deoxy-D-glucose $(10 \mathrm{mM})$ and antimycin $\mathrm{A}(\mathrm{I} \mu \mathrm{M})$ for $40 \mathrm{~min}$ at $37^{\circ} \mathrm{C}$ before challenging with stimulus. $* P<0.05$ compared with the corresponding uninhibited controls.

mice. Normal rat and hamster IgG isotype controls tested had little effect on TM-N49 induced mast cell accumulation (Table 5).

\section{Discussion}

As a novel subgroup of snake venom group II PLA P $_{2}$ the proinflammatory activities of N49 PLA have not yet been studied. Therefore, this is the first study to investigate the potential actions of N49 $\mathrm{PLA}_{2}$ in inflammation. TM-N49 was found to be a potent stimulus of microvascular leakage in the skin of rats. The potency of this unique, inactive $\mathrm{PLA}_{2}$ in induction of microvascular leakage is similar to the potency of bradykinin and histamine on a molar basis. Therefore it is not difficult to anticipate that TM$\mathrm{N} 49$ by itself should be able to induce severe inflammatory reactions upon snake bite.

Since histamine/5-HT antagonist cyproheptadine abolished the TM-N49-induced microvascular leakage, but selective histamine $\mathrm{H}_{1}$ receptor antagonist terfenadine did not, the action of TM-N49 on skin edema seems to be histamine independent. It is likely that 5-HT and other mast cell products, such as PAF, serine proteases, leukotrienes, prostaglandins are involved in the process [24]. Indeed, it was observed that ginkgolide $\mathrm{B}$, a PAF receptor antagonist inhibited microvascular leakage induced by TM-N49, suggesting that PAF was involved in the microvascular leakage process. Mast cell mediated edema formation in response to different snake venom $\mathrm{PLA}_{2}$ has been reported previously. Thus, $\mathrm{PLA}_{2}$ from Vipera russeli, Naja mocambique and honey bee produced a rapid but transient oedematous response in rat paw [25]. Bothropstoxin-I and bothropstoxin-II, two K49 $\mathrm{PLA}_{2} \mathrm{~s}$ isolated from Bothrops jararacussu snake venom caused dose-dependent rat paw and skin oedema formation [17]. PLA 2 s from Crotalus durissus cascavella, Crotalus durissus collilineatus and Crotalus durissus terrificus venoms increased the vascular permeability in the rat skin [26]. However, the observed reduction of mast cell numbers by injection of compound 48/80 hardly affects the inflammatory potential of TMN49: even a 10-fold reduction in detectable mast cells does not result in a significant reduction of extravasation. This implied that mast cell activation may not be the relevant mechanism for TM-N49 induced skin edema. It is difficult to exclude the possibility that TM-N49 bound to a receptor of $\mathrm{PLA}_{2}$ and caused microvascular leakage, though the latter has not yet been identified. Recently, it was found that snake venom catalytically inactive PLA 2 homologue could binds to vascular endothelial growth factor receptor-2 via a C-terminal loop region, exhibiting mast cell unrelated mechanism for the increased the vascular permeability [27].

In order to study the activation of mast cells by TM-N49, mast cell challenge experiments were performed. TM-N49 can activate human colon, lung and tonsil mast cells in a

Table 2: The effect of pertussis toxin on TM-N49 induced histamine release from human mast cells

\begin{tabular}{|c|c|c|c|c|c|c|c|}
\hline \multirow{3}{*}{$\begin{array}{l}\text { Compound } \\
(\mu \mathrm{g} / \mathrm{ml})\end{array}$} & & \multicolumn{6}{|c|}{ Net histamine release (\%) } \\
\hline & & \multicolumn{3}{|c|}{ Without pertussis toxin } & \multicolumn{3}{|c|}{ With pertussis toxin } \\
\hline & & Lung & Colon & Tonsil & Lung & Colon & Tonsil \\
\hline \multirow[t]{2}{*}{ TM-N49 } & 3.0 & $9.3 \pm 1.9$ & $13.5 \pm 3.0$ & $8.0 \pm 2.0$ & $0.8 \pm 1.8^{*}$ & $0.1 \pm 2.2^{*}$ & $1.5 \pm 1.3^{*}$ \\
\hline & 30 & $14.7 \pm 4.7$ & $29.6 \pm 6.8$ & $62.0 \pm 8.5$ & $4.0 \pm 0.6^{*}$ & $3.9 \pm 3.9 *$ & $31.9 \pm 9.2 *$ \\
\hline Anti-lgE & 10 & $17.3 \pm 5.4$ & $17.4 \pm 5.1$ & $\mathrm{II} . \mathrm{I} \pm 3.4$ & $2.1 \pm 1.1 *$ & $0.9 \pm 1.2^{*}$ & $3.0 \pm 0.3^{*}$ \\
\hline $\mathrm{Cl}$ & 0.5 & $24.4 \pm 6.3$ & $38.8 \pm 4.6$ & $37 \pm 9.3$ & $19.6 \pm 4.8$ & $30.4 \pm 2.8$ & $20.4 \pm 4.4$ \\
\hline
\end{tabular}

The values shown are mean \pm SE for four to five separate experiments performed in duplicate. Cells were incubated withl $.0 \mu \mathrm{g} / \mathrm{ml}$ pertussis toxin for $4 \mathrm{~h}$ at $37^{\circ} \mathrm{C}$ before challenging with stimulus. $* P<0.05$ compared with the corresponding uninhibited controls. 


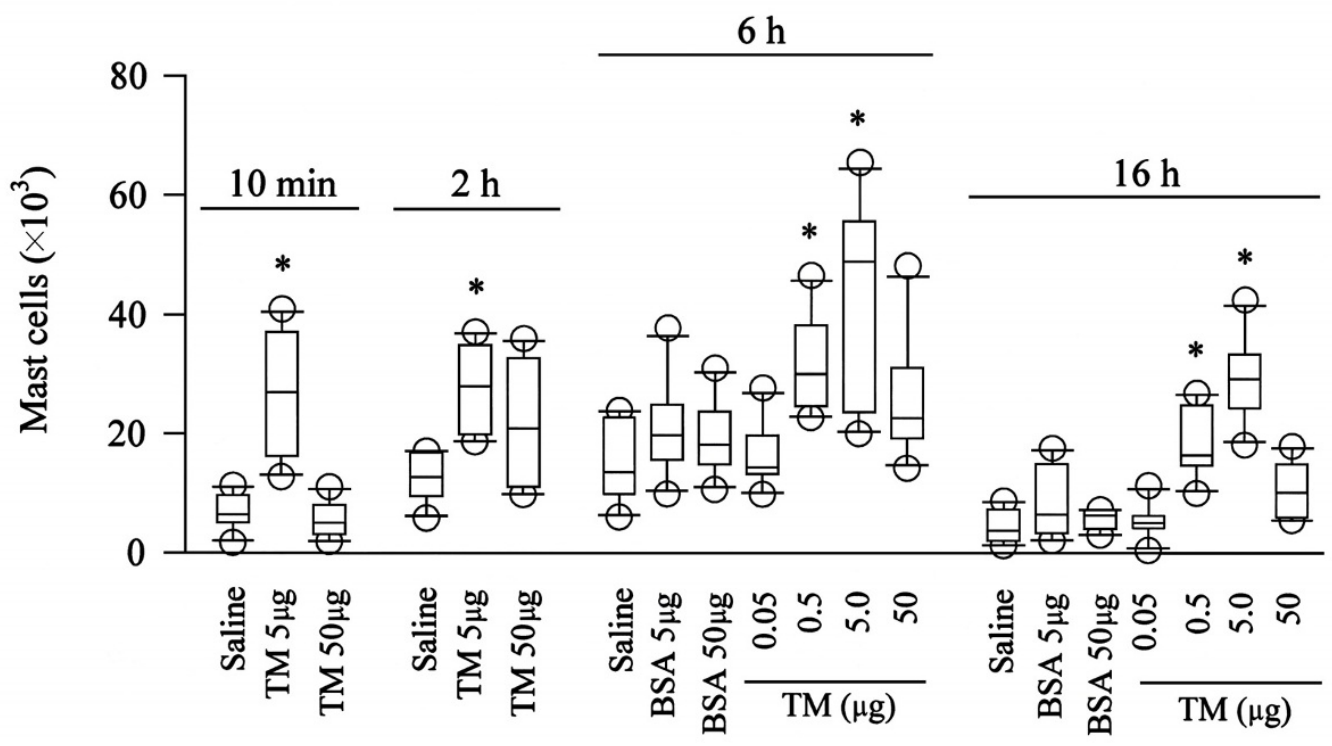

\section{Figure 6}

Effect of TM-N49 (TM) on mast cell numbers in mouse peritoneum. Various doses of TM-N49 were injected into the peritoneum of mice for $10 \mathrm{~min}, 2 \mathrm{~h}, 6 \mathrm{~h}$ or $16 \mathrm{~h}$. Also shown are the responses to BSA and normal saline control. Data are displayed as a boxplot, which indicates the median, interquartile range, the largest and smallest values other than outliers $(O)$ (defined as those which are more than I.5 box lengths from the median) for 6 animals in each group. $* P<0.05$ compared with the response to the corresponding diluent only control animals.

dose dependent manner. It was discovered further that TM-N49 induced mast cell degranulation is an energy consuming process and involved a $\mathrm{G}$ protein coupled receptor in mast cells [28] as both metabolic inhibitors and pertussis toxin were capable of inhibiting TM-N49 elicited histamine release from mast cells. It was reported previously that $\mathrm{PLA}_{2} \mathrm{~s}$ were able to directly activate rat mast cells in vitro $[17,20,29]$. The action of D49 $\mathrm{PLA}_{2} \mathrm{~s}$ on rat mast cells was dependent on their catalytic activity $[16,30]$, whereas the influence of $\mathrm{K} 49 \mathrm{PLA}_{2} \mathrm{~s}$, which possess negligible catalytic activity, on rat mast cells was through a heparin-sensitive mechanism [17]. Removal of $\mathrm{Ca}^{2+}$ and $\mathrm{Mg}^{2+}$ from challenge buffer greatly reduced the cell response to the stimulation of TM-N49 indicated that exogenous calcium and magnesium ions were crucial for mast cell degranulation induced by TM-N49. The increased serotonin level in mouse peritoneal lavage fluid supplied further evidence on TM-N49 causing mast cell degranulation in rats as mast cells are major source (if not the only source) of serotonin in mouse peritoneum. The most relevant mast cell population in regard to snake bites would be skin mast cells which differ in phenotype and activating stimuli from other mast cell populations. From those populations investigated, tonsil mast cells most closely resemble skin mast cells [31]. Interestingly, as shown in figure 4, tonsil mast cells only responded to

Table 3: Effect of TM-N49 on relative mast cell numbers in mouse peritoneum following injection.

\begin{tabular}{lllll}
\hline TM-N49 $(\mu \mathrm{g})$ & \multicolumn{3}{c}{ Percentage of mast cells in total nucleated cells } \\
\cline { 2 - 5 } & $10 \mathrm{~min}$ & $2 \mathrm{~h}$ & $6 \mathrm{~h}$ & $16 \mathrm{~h}$ \\
\hline Saline & $0.49(0.40-0.96)$ & $0.45(0.31-1.30)$ & $0.56(0.23-0.76)$ & $0.85(0.29-1.88)$ \\
50 & $0.16(0.06-0.35)^{*}$ & $0.24(0.08-0.78)^{*}$ & $0.36(0.21-0.90)$ & $0.05(0.03-0.11)^{*}$ \\
5.0 & $0.76(0.44-1.11)$ & $1.05(0.60-1.77)^{*}$ & $0.67(0.29-1.76)$ & $0.51(0.22-1.36)$ \\
0.5 & n.d & n.d & $0.61(0.39-1.00)$ & $0.63(0.27-1.10)$ \\
0.05 & n.d & n.d & $0.90(0.39-2.67)$ & $1.10(0.47-1.31)$ \\
\hline
\end{tabular}

Various doses of TM-N49 were injected into the peritoneum of mice for $10 \mathrm{~min}, 2 \mathrm{~h}, 6 \mathrm{~h}$ or $16 \mathrm{~h}$. Also shown are the responses to normal saline control. Relative number of mast cells was defined as the percentage of mast cell in total nucleated cells. $* P<0.05$ compared with the response to saline alone. 
Table 4: The influence of anti-inflammatory compounds on TM-N49 $(5 \mu \mathrm{g})$ induced mast cell accumulation in mouse peritoneum

\begin{tabular}{|c|c|c|}
\hline Compound injected & & Number of mast cells $\left(\times 10^{3}\right)$ \\
\hline Saline & & $14.6(6 . \mid-23)$ \\
\hline TM-N49 & & $49.3(20.3-65.9)$ \\
\hline Ginkgolide B & $5 \mathrm{mg} \cdot \mathrm{kg}^{-1}$ & $26.2(9 . I-4 I)$ \\
\hline Ginkgolide B & $5 \mathrm{mg} \cdot \mathrm{kg}^{-1}+\mathrm{TM}-\mathrm{N} 49$ & $19.6(10-26)^{*}$ \\
\hline Cyproheptadine & $2 \mathrm{mg} \cdot \mathrm{kg}^{-1}$ & $6.2(1.5-17.2)$ \\
\hline Cyproheptadine & $2 \mathrm{mg} \cdot \mathrm{kg}^{-1}+\mathrm{TM}-\mathrm{N} 49$ & $21.9(10.1-28.7)^{*}$ \\
\hline Terfenadine & $2 \mathrm{mg} \cdot \mathrm{kg}^{-1}$ & II.0 (5.8-20) \\
\hline Terfenadine & $2 \mathrm{mg} \cdot \mathrm{kg}^{-1}+\mathrm{TM}-\mathrm{N} 49$ & $9.5(4.0-13.2)^{*}$ \\
\hline Quinacrine & $10 \mathrm{mg} \cdot \mathrm{kg}^{-1}$ & $11.5(5.9-18.1)$ \\
\hline Quinacrine & $10 \mathrm{mg} \cdot \mathrm{kg}^{-1}+\mathrm{TM}-\mathrm{N} 49$ & $59.7(40.5-73.3)$ \\
\hline
\end{tabular}

The values shown are medians (range) for six separate experiments. Compounds were injected into the mouse peritoneum for $6 \mathrm{~h}$ before peritoneal lavage fluid being collected. $* P<0.05$ compared with the response to TM-N49 alone.

rather high concentrations of TM-N49, and the overall release $(\sim 7 \%)$ is very little compared to other venom components (e.g. atrahagin, induces $26 \%$ histamine release) [23]. TM-N49 at $30 \mu \mathrm{g}$ appears to be toxic, as the observed release is later shown to be $\mathrm{Ca}^{2+}$-independent. This, again, indicates that mast cell activation may not be the relevant mechanism for TM-N49 induced inflammation.

With a mouse peritoneal model, it was found for the first time that snake venom PLA 2 could induce mast cell accumulation even at $10 \mathrm{~min}$ following injection. This appeared not a mast cell-specific effect since the relative number of mast cells in total nucleated cells was not significantly altered. The action of TM-N49 in induction of mast cell accumulation could be inhibited by co-injection of TM-N49 with ginkgolide B, cyproheptadine and terfenadine, suggesting that histamine, 5-HT and PAF may play a role in mast cell accumulation induced by TM-N49. Antibodies specific for CD18, CD11a and ICAM-1 blocked TM-N49 induced mast cell accumulation, while

Table 5: The influence of blocking antibodies $(\mathrm{Ab})$ against cell adhesion molecules on TM-N49 $(5.0 \mu \mathrm{g})$ induced mast cell accumulation in mouse peritoneum

\begin{tabular}{lll}
\hline Compound injected & Number of mast cells $\left(\times 10^{3}\right)$ \\
\hline Saline & $14.6(6.1-23)$ \\
TM-N49 & $49.3(20.3-65.9)$ \\
L-selectin Ab & + TM-N49 & $38.0(19.1-68.8)$ \\
LFA-I Ab & + TM-N49 & $33.7(18.9-55.2) *$ \\
CDI8 Ab & + TM-N49 & $25.1(10.4-39.8)^{*}$ \\
ICAM-I Ab & + TM-N49 & $14.8(9.6-32.0)^{*}$ \\
Hamster IgGI & + TM-N49 & $39.8(17.0-63.1)$ \\
Rat IgG2a & + TM-N49 & $43.3(19.3-58.0)$ \\
\hline
\end{tabular}

The values shown are medians (range) for six separate experiments. Monoclonal antibodies (all at a dose of $\mathrm{I} \mathrm{mg}^{\circ} \mathrm{kg}^{-1}$ ) against the adhesion molecules L-selectin, LFA-I, CDI8 and ICAM-I were intravenously injected, respectively for $30 \mathrm{~min}$ before intra-peritoneal injection of 5 $\mu \mathrm{g}$ of TM-N49 for $6 \mathrm{~h}$. $* P<0.05$ compared with the response to TMN49 alone.
L-selectin specific antibody failed to do so. These observations suggested that LFA-1 (CD11a/CD18) and ICAM-1, but not L-selectin were involved in the TM-N49 induced mast cell migration process. Involvement of CD11a/ CD18 and ICAM-1 in mast cell migration was reported previously with Saban et al. [32,33]. Since mast cells and endothelial cells express both LFA-1 and ICAM-1 [32,33], we believe that CD11/CD18 and ICAM-1 are important adhesion molecules for TM-N49 induced mast cell migration. The increase in mast cell numbers could be regarded as a beneficial host response since mast cells were shown to be able to detoxify venom components [21].

\section{Conclusion}

A novel snake venom group II PLA 2 , TM-N49 was able to induce a dramatic increase in microvascular permeability in the skin of rats. The action of TM-N49 appeared to be unrelated to the activation of mast cells. Indeed, it was confirmed that TM-N49 was able to stimulate mast cell degranulation and accumulation. The ability of TM-N49 in induction of microvascular leakage, mast cell degranulation and mast cell infiltration implicates that it is a potent proinflammatory factor in snake venom.

\section{Methods \\ Reagents}

Protobothrops mucrosquamatus crude venom was obtained from the stock of the Kunming Institute of Zoology, the Chinese Academy of Sciences. SP-sephadex C-25, heparin sepharose (FF) and superdex 75 were from LKB Pharmacia (Uppsala, Sweden). The following compounds were purchased from Sigma (St. Louis, USA): egg phosphatidyl choline, Triton X-100, trifluoroacetic acid, honey bee venom phospholipase A2, platelet activating factor (PAF), cyproheptadine, ginkgolide $\mathrm{B}$, heparin, collagenase (type I), hyaluronidase (type I), soybean trypsin inhibitor (SBTI), bovine serum albumin (BSA, fraction V), penicillin and streptomycin, calcium ionophore A23187, antimycin A, 2-deoxy-D-glucose, pertussis toxin. Quina- 
crine was from Calbiochem (San Diego, CA, USA). Reagents for sodium dodecyl- sulphate-polyacrylamine gel electrophoresis (SDS-PAGE) were from Bio-Rad Laboratories Inc (Hercules, USA). Coomassie Plus ${ }^{\mathrm{TM}}$ assay kit was from Pierce Chemical Co (Rockford, IL, USA). PolyATract system 1000 kit and Reverse transcription system kit were from Promega Biotech (Madison, WI, USA). Goat antihuman IgE (inactivated) was from Serotec (Kidlington, Oxford, UK). Fetal calf serum (FCS) and minimum essential medium (MEM) containing $25 \mathrm{mM} \mathrm{N}$-2-hydroxylethylpiperazine-N'-2 -ethane sulphonic acid (HEPES) were from Gibco (Paisley, Renfrewshire, UK). Rat monoclonal antibodies, anti-mouse CD 11a [lymphocyte function-associated antigen 1(LFA-1) $\alpha$ chain], clone M17/4; anti-mouse CD 62L (L-selectin), clone MEL-14; antimouse CD18 (integrin $\beta_{2}$ chain), clone M18/2; rat IgG2a isotype standard, clone R35-95; hamster anti-mouse CD54 [intercellular adhesion molecule 1 (ICAM-1)] monoclonal antibody, clone 3E2; hamster IgG1 isotype standard, clone A19-3 were from BD Biosciences Pharmigen (CA, USA). Hepes and all other chemicals were of analytical grade. BALB/c mice (20-25 g) and Wistar rat (180$220 \mathrm{~g})$ were bred and reared under strict ethical conditions according to international recommendation.

\section{Purification of TM-N49}

TM-N49 was isolated from Protobothrops mucrosquamatus crude venom following the procedures described previously [6]. Briefly, the lyophilized venom (1.5 g) was dissolved in $20 \mathrm{ml}$ of $50 \mathrm{mM}$ sodium phosphate buffer $(\mathrm{pH}$ 5.8) and loaded on a SP-sephadex C-25 column equilibrated with the same buffer. The absorbed proteins were eluted with a linear gradient of $\mathrm{NaCl}(0-0.8 \mathrm{M})$ in $50 \mathrm{mM}$ sodium phosphate ( $\mathrm{pH}$ 5.8). The fractions in peak 9 were collected, lyophilized, and then dissolved in a running buffer containing $25 \mathrm{mM}$ sodium phosphate $(\mathrm{pH} 5.8)$ and $0.15 \mathrm{M} \mathrm{NaCl}$. Superdex 75 column was used to further isolate TM-N49 and the fractions 50-56 in the main protein peak was collected and loaded on a heparin-sepharose (FF) column equilibrated with a $25 \mathrm{mM}$ sodium phosphate buffer ( $\mathrm{pH}$ 5.8). The absorbed proteins were eluted with a linear gradient of $\mathrm{NaCl}(0-0.8 \mathrm{M})$ in $25 \mathrm{mM}$ sodium phosphate ( $\mathrm{pH} 5.8$ ). The fractions $40-47$ in the main protein peak eluted from heparin agarose were collected, lyophilized, dissolved in $0.1 \%$ trifluoroacetic acid $(\mathrm{v} / \mathrm{v})$ and loaded on a reverse-phase $\mathrm{C}_{18}$ high performance liquid chromatography colomn (Symmetry 300 ${ }^{\mathrm{TM}}, 5 \mu \mathrm{M}$; Waters Corporation, Milford, Massachusetts, USA). The elution was performed with $0.1 \%$ trifluoroacetic acid and a gradient of $15-75 \%$ buffer B (containing 100\% acetonitrile (v/v) and $0.1 \%$ trifluoroacetic acid) over $60 \mathrm{~min}$ at a flow rate of $1 \mathrm{ml} / \mathrm{min}$. The fractions in main protein peak representing the purified TM-N49 were pooled, lyophilized and analyzed with mass spectrometer and stored at $-20^{\circ} \mathrm{C}$ until use. Protein concentration was deter- mined by a modified Bradford method [34] using a Coomassie Plus ${ }^{\mathrm{TM}}$ assay kit with BSA as standard. The PLA 2 activity was routinely assayed by a titration method using egg yolk as substrate according to Ishimaru et al. [35], and by a colorimetric assay using L-phosphatidylcholine as substrate according to de Ajaujo and Radvanyi [36]. Honey bee PLA 2 was employed as positive control.

\section{Induction of microvascular leakage}

Microvascular leakage experiments were performed mainly following the procedures described previously by He et al. [37]. Briefly, Wistar rats (180-220 g) were anaesthetized by intra-peritoneal injection of sodium pentobarbitone at a dose of $21 \mathrm{mg} \cdot \mathrm{kg}^{-1}$. After shaving the back, 1\% $(\mathrm{w} / \mathrm{v})$ Evan's blue dye in normal saline was injected intravenously into the tail vein, and then various doses of TMN49, bradykinin, histamine and PAF all at $5 \mu \mathrm{g}, \mathrm{BSA}$ at 5 $\mu \mathrm{g}$ and $50 \mu \mathrm{g}$ or normal saline were intradermally injected, randomized sites placed $2-3 \mathrm{~cm}$ apart, $50 \mu \mathrm{l}$ per injection point. Animals were kept warm, and at $20 \mathrm{~min}$ following the final injection, were killed by inhalation of carbon dioxide and the skin removed. Two perpendicular diameters were recorded for the blue area on the inside of the skin, and multiplied to give a measure of the relative size of the area of cutaneous edema.

For compound 48/80 pretreatment experiments, groups of rats (including $6 \mathrm{~h}$, day 1 , day 2, day 3, day 4 groups and their corresponding control groups) were treated with compound $48 / 80$ to deplete mast cells, as described by Di Rosa et al. [38]. Briefly, compound 48/80 (0.1\% solution in $0.9 \%$ sterile saline) was injected intravenously at a dose of $0.6 \mathrm{mg} \cdot \mathrm{kg}^{-1}$, twice a day for 3 days, and doubled dose in day 4 . At $5 \mathrm{~h}$ following the final injection, the test substances in the skin oedema experiments were administered as described above. The control groups received a normal saline injection. Both skins and peritoneal lavages of the testing rats were collected and analyzed.

To investigate potential mechanisms involved in TM-N49 induced microvascular leakage, several anti-inflammatory compounds including cyproheptadine $(5 \mu \mathrm{g})$, a $5-\mathrm{HT}_{2} / 5$ $\mathrm{HT}_{1 \mathrm{C}}$ serotonin receptor antagonist and $\mathrm{H}_{1}$ histamine receptor antagonist; terfenadine $(5 \mu \mathrm{g})$, a selective $\mathrm{H}_{1}$ histamine receptor antagonist; ginkgolide $\mathrm{B}(5 \mu \mathrm{g})$, a PAF receptor antagonist [39] and quinacrine (5 $\mu \mathrm{g})$, an inhibitor of $\mathrm{PLA}_{2}$ [40] were co-injected into the skin of rats with TM-N49 PLA 2 ( $5 \mu \mathrm{g})$, bradykinin $(5 \mu \mathrm{g})$, histamine $(5 \mu \mathrm{g})$, or normal saline respectively for $20 \mathrm{~min}$.

\section{Mast cell challenge and analysis of histamine release}

Macroscopically normal lung and colon tissues were collected at bronchial or colon resection from patients with lung or colon cancer, respectively, and tonsil tissue was obtained at tonsillectomy. The procedure for mast cell dis- 
persion was similar to that described previously $[23,28]$. Briefly, tissue was chopped finely with scissors into fragments of $0.5-2.0 \mathrm{~mm}^{3}$, and incubated with $1.5 \mathrm{mg} / \mathrm{ml}$ collagenase and $0.75 \mathrm{mg} / \mathrm{ml}$ hyaluronidase in MEM containing 2\% FCS (1 g lung/10 ml buffer) for $70 \mathrm{~min}$ at $37^{\circ} \mathrm{C}$. Dispersed cells were separated from undigested tissue by filtration through nylon gauze (pore size $100 \mu \mathrm{m}$ diameter), and were maintained in MEM (containing $10 \%$ FCS, $200 \mathrm{U} / \mathrm{ml}$ penicillin, $200 \mu \mathrm{g} / \mathrm{ml}$ streptomycin) on a roller overnight at room temperature. Mast cell numbers were determined by light microscopy after staining with alcine blue staining solution, and represented 2.5 to $5.3 \%, 4.2$ to $5.7 \%$, and 1.2 to $3.1 \%$ of nucleated cells in lung, colon or tonsil suspensions, respectively.

Prior to challenge with stimulus the cells were washed with HBSS ( $\mathrm{pH} 7.4$ ) without added calcium or magnesium $\left(500 \mathrm{~g}, 10 \mathrm{~min}, 25^{\circ} \mathrm{C}\right)$, and then resuspended in HBSS with $1.8 \mathrm{mM} \mathrm{CaCl}_{2}$ and $0.5 \mathrm{mM} \mathrm{MgCl}_{2}$. Aliquots of $100 \mu \mathrm{l}$ containing $4-6 \times 10^{3}$ mast cells were added to a 50 $\mu \mathrm{l}$ aliquot of purified TM-N49, heparin, or control secretagogue in complete HBSS and incubated for $15 \mathrm{~min}$ at $37^{\circ} \mathrm{C}$. The reaction was terminated by the addition of 150 $\mu \mathrm{l}$ ice cold HBSS and the tubes centrifuged immediately $\left(500 \mathrm{~g}, 10 \mathrm{~min}, 4^{\circ} \mathrm{C}\right.$ ). All experiments were performed in duplicate. For the measurement of total histamine concentration the suspension in some tubes was boiled for 6 min. Supernatants were stored at $-20^{\circ} \mathrm{C}$ until histamine concentrations were determined. Where added, TM-N49 at $30 \mu \mathrm{g} / \mathrm{ml}$ was preincubated with heparin on ice for 10 min before being added to cells.

For the experiments with pertussis toxin, cells were incubated with 0.1 or $1.0 \mu \mathrm{g} / \mathrm{ml}$ pertussis toxin for $4 \mathrm{~h}$ at $37^{\circ} \mathrm{C}$, and then washed with HBSS before adding stimulus. Similarly, for the experiments with metabolic inhibitors, cells were incubated with 2-deoxy-D-glucose $(10 \mathrm{mM})$ and antimycin $\mathrm{A}(1 \mu \mathrm{M})$ for $40 \mathrm{~min}$ at $37^{\circ} \mathrm{C}$ before challenged with stimulus.

A glass fibre-based, fluorometric assay was employed to determine histamine levels in supernatants, as previously described $[23,28]$. Histamine bound to a glass-fibre matrix (RefLab, Copenhagen, Denmark) was detected by addition of o-phthaldialdehyde (OPT) and the color change measured using a spectrophotofluorometer (Perkin-Elmer LS 2, Denmark). Histamine release was expressed as a percentage of total cellular histamine levels, and corrected for the spontaneous release measured in tubes in which cells had been incubated with the HBSS diluent alone. For the time course study, data were presented as percentage of maximum histamine release, which equals (actual net histamine release/maximum net histamine release induced by the testing compound) $x$ $100 \%$.

\section{Induction of mast cell accumulation}

Various doses of TM-N49, BSA or normal saline were injected in $0.5 \mathrm{ml}$ volumes into the peritoneum of male BALB/c mice, whose abdominal skin was swabbed with $70 \%$ ethanol, a group of 6 mice for each dose. This model was adapted from that described by Thomas et al. [41], which complied with the European Community guidelines for use of experimental animals. At $10 \mathrm{~min}, 2 \mathrm{~h}, 6 \mathrm{~h}$ or $16 \mathrm{~h}$ following injection, animals were sacrificed by inhalation of carbon dioxide, and their peritoneal lavages were collected following a standardized procedure with 5 $\mathrm{ml}$ normal saline using heparinised tubes. After centrifugation at $500 \mathrm{~g}$ for $10 \mathrm{~min}$ at $4^{\circ} \mathrm{C}$, supernatants were collected and stored at $-40^{\circ} \mathrm{C}$ until use, and cells were resuspended in $1 \mathrm{ml}$ of MEM. The total cell numbers were determined by enumerating them with an Improved Neubauer haemocytometer after being stained with $0.1 \%$ trypan blue. For the differential cell counting, cytocentrifuge preparations were made, air dried and stained with modified Wright's stain. Differential cell counts were performed for a minimum of 500 cells. The results were expressed as absolute numbers of each cell type per mouse peritoneum.

For the experiments investigating mast cell migration mechanisms, groups of mice were pretreated intravenously (tail vein injection) with monoclonal antibodies against the adhesion molecules L-selectin, CD11a, CD18 and ICAM-1 (all at a dose of $1 \mathrm{mg} \cdot \mathrm{kg}^{-1}$ ) [42-44], respectively for $30 \mathrm{~min}$ before intra-peritoneal injection of $5 \mu \mathrm{g}$ TM-N49. Control animals received an equivalent dose of the corresponding normal rat or hamster IgG isotype control. At $6 \mathrm{~h}$ following injection, the mice were sacrificed and their peritoneal lavages were processed as described above.

To investigate potential mechanisms involved in TM-N49 induced inflammatory cell accumulation, several antiinflammatory compounds including cyproheptadine (2 $\left.\mathrm{mg} \cdot \mathrm{kg}^{-1}\right)$ [17], terfenadine $\left(3 \mathrm{mg} \cdot \mathrm{kg}^{-1}\right) \quad[45,46]$, ginkgolide $\mathrm{B}\left(5 \mathrm{mg} \cdot \mathrm{kg}^{-1}\right)$ [39] and quinacrine $(10 \mathrm{mg} \cdot \mathrm{kg}$ 1) [40] were co-injected into the peritoneum of mice with TM-N49 ( $5 \mu$ g per mouse). Control animals received an injection of drug alone. At $6 \mathrm{~h}$ following injection, mice were sacrificed and their peritoneal lavages were processed as described above. Certain mice were pretreated with compound $48 / 80$ for 4 days as described above before peritoneal injection of $5 \mu \mathrm{g}$ of TM-N49.

\section{Statistical analysis}

Statistical analyses were performed using SPSS software (version 12.0). For in vitro experiments, because data were normally distributed, they are shown as the mean \pm SEM. for the number of experiments indicated. Where analysis of variance indicated significant differences between 
groups, for the preplanned comparisons of interest, paired Student's $t$ test was applied. For in vivo experiments, since the data were not normally distributed, they were presented as the median and range, for the numbers of animals indicated. Where Kruskal-Wallis analysis indicated significant differences between groups, for the preplanned comparisons of interest the Mann-Whitney $U$-test was employed. For all analyses, $P<0.05$ was taken as significant.

\section{Authors' contributions}

JFW and SHH conceived and designed the study. JFW, XLW and YZM performed the experiments. JFW drafted the manuscript and SHH revised the manuscript. SHH supervised and coordinated the whole project. All authors have read and approved the final manuscript.

\section{Acknowledgements}

We are grateful to Miss Jie-lian Lin and Miss Qiu-Yu Chen for their assistants in the animal experiments. This project was sponsored by the Major State Basic Research Program of China (973 Program) (No.

2007CB5 I 2400) and the National Natural Science Foundation of China (No. 30801016, 305708I3, 30772032).

\section{References}

I. Verheij HM: Phospholipases in clinical inflammation. Edited by: Glaser KB, Vadas P. Boca Raton FL: CRC Press; 1996:3-24.

2. Dennis EA: The enzymes. Edited by: Boyer PD. New York: Academic Press; 1983:307-353.

3. Dufton MJ, Eaker D, Hider RC: Conformational properties of phospholipases $A_{2}$. Secondary-structure prediction, circular dichroism and relative interface hydrophobicity. Eur J Biochem 1983, 137:537-544.

4. Maraganore JM, Merutka G, Cho W, Welches W, Kézdy FJ, Heinrikson RL: A new class of phospholipases $A_{2}$ with lysine in place of aspartate 49. Functional consequences for calcium and substrate binding. J Biol Chem 1984, 259:13839-13843.

5. Maraganore JM, Heinrikson RL: The lysine-49 phospholipase A2 from the venom of Agkistrodon piscivorus piscivorus. Relation of structure and function to other phospholipases $A_{2}$. J Biol Chem 1986, 26 I:4797-4804.

6. Wei JF, Wei XL, Chen QY, Huang T, Qiao LY, Wang WY, Xiong YL, $\mathrm{He} \mathrm{SH}$ : $\mathbf{N} 49$ phospholipase $\mathbf{A}_{2}$, a unique subgroup of snake venom group II phospholipase $\mathbf{A}_{2}$. Biochim Biophys Acta 2006, | 760:462-47|.

7. Rojnuckarin P, Muanpasitporn C, Chanhome L, Arpijuntarangkoon J, Intragumtornchai T: Molecular cloning of novel serine proteases and phospholipases A2 from green pit viper (Trimeresurus albolabris) venom gland cDNA library. Toxicon 2006, 47:279-287.

8. Tsai IH, Wang YM, Chen YH, Tsai TS, Tu MC: Venom phospholipases $A_{2}$ of bamboo viper (Trimeresurus stejnegeri): molecular characterization, geographic variations and evidence of multiple ancestries. Biochem J 2004, 377:2 I 5-223.

9. Lu QM, Jin Y, Wei JF, Li DS, Zhu SW, Wang WY, Xiong YL: Characterization and cloning of a novel phospholipase $A_{2}$ from the venom of Trimeresurus jerdonii snake. Toxicon 2002, 40:1313-1319.

10. Lu QM, Jin Y, Wei JF, Wang WY, Xiong YL: Biochemical and biological properties of Trimeresurus jerdonii venom and characterization of a platelet aggregation-inhibiting acidic phospholipase $\mathbf{A}_{2}$. J Nat Toxins 2002, I I:25-33.

II. Kini RM: Structure-function relationships and mechanism of anticoagulant phospholipase $A_{2}$ enzymes from snake venoms. Toxicon 2005, 45:||47-|161.

12. Tsai IH, Lu PJ, Wang YM, Ho CL, Liaw LL: Molecular cloning and characterization of a neurotoxic phospholipase $A_{2}$ from the venom of Taiwan habu (Trimeresurus mucrosquamatus). Biochem J 1995, 3 I I:895-900.

13. Soares AM, Guerra-Sá R, Borja-Oliveira CR, Rodrigues VM, Rodrigues-Simioni L, Rodrigues V, Fontes MR, Lomonte B, Gutiérrez JM, Giglio JR: Structural and functional characterization of BnSP7, a Lys49 myotoxic phospholipase $A_{2}$ homologue from Bothrops neuwiedi pauloensis venom. Arch Biochem Biophys 2000, 378:20I-209.

14. Soares AM, Andrião-Escarso SH, Angulo Y, Lomonte B, Gutiérrez JM, Marangoni S, Toyama MH, Arni RK, Giglio JR: Structural and functional characterization of myotoxin I, a Lys49 phospholipase $A_{2}$ homologue from Bothrops moojeni (Caissaca) snake venom. Arch Biochem Biophys 2000, 373:7-15.

15. Kanashiro MM, de Cássia M, Escocard R, Petretski JH, Prates MV, Alves EW, Machado OL, da Silva WD, Kipnis TL: Biochemical and biological properties of phospholipases $A_{2}$ from Bothrops atrox snake venom. Biochem Pharmacol 2002, 64: I I79-1 I 86.

16. Lloret $\mathrm{S}$, Moreno JJ: Oedema formation and degranulation of mast cells by phospholipase $A_{2}$ purified from porcine pancreas and snake venoms. Toxicon 1993, 3 I:949-956.

17. Landucci EC, Castro RC, Toyama M, Giglio JR, Marangoni S, De Nucci $G$, Antunes E: Inflammatory oedema induced by the lys-49 phospholipase $A_{2}$ homologue piratoxin-i in the rat and rabbit. Effect of polyanions and p-bromophenacyl bromide. Biochem Pharmacol 2000, 59:1289-1294.

18. Teixeira CF, Landucci EC, Antunes E, Chacur M, Cury Y: Inflammatory effects of snake venom myotoxic phospholipases $\mathbf{A}_{\mathbf{2}}$. Toxicon 2003, 42:947-962.

19. Zuliani JP, Gutiérrez JM, Casais e Silva LL, Coccuzzo Sampaio S, Lomonte B, Teixeira CF: Activation of cellular functions in macrophages by venom secretory Asp-49 and Lys-49 phospholipases $A_{2}$. Toxicon 2005, 46:523-532.

20. Landucci EC, Castro RC, Pereira MF, Cintra AC, Giglio JR, Marangoni $S$, Oliveira B, Cirino G, Antunes E, De Nucci G: Mast cell degranulation induced by two phospholipase $A_{2}$ homologues: dissociation between enzymatic and biological activities. Eur J Pharmacol 1998, 343:257-263.

21. Metz M, Piliponsky AM, Chen CC, Lammel V, Abrink M, Pejler G, Tsai M, Galli SJ: Mast cells can enhance resistance to snake and honeybee venoms. Science 2006, 3 13:526-530.

22. Schneider LA, Schlenner SM, Feyerabend TB, Wunderlin M, Rodewald HR: Molecular mechanism of mast cell mediated innate defense against endothelin and snake venom sarafotoxin. J Exp Med 2007, 204:2629-2639.

23. Wei JF, Mo YZ, Qiao LY, Wei XL, Chen HQ, Xie H, Fu YL, Wang WY, Xiong YL, He SH: Potent histamine-releasing activity of atrahagin, a novel snake venom metalloproteinase. Int J Biochem Cell Biol 2006, 38:5I0-520.

24. Desouza IA, Ribeiro-DaSilva G: The pharmacological profile of mouse hind paw inflammation induced by staphylococcal enterotoxin type A. Inflamm Res 1997, 46:36I-365.

25. Cirino G, Peers SH, Flower RJ, Browning JL, Pepinsky RB: A study of phospholipase A2-induced oedema in rat paw. Eur J Pharmacol 1989, 166:505-510.

26. Câmara PR, Esquisatto LC, Camargo EA, Ribela MT, Toyama MH, Marangoni S, De Nucci G, Antunes E: Inflammatory oedema induced by phospholipases $A_{2}$ isolated from Crotalus durissus sp. in the rat dorsal skin: a role for mast cells and sensory $C$ fibers. Toxicon 2003, 41:823-829.

27. Fujisawa D, Yamazaki Y, Lomonte B, Morita T: Catalytically inactive phospholipase A2 homologue binds to vascular endothelial growth factor receptor-2 via a C-terminal loop region. Biochem J 2008, 4I I:5 I5-522.

28. He S, Gaça MD, Walls AF: A role for tryptase in the activation of human mast cells: modulation of histamine release by tryptase and inhibitors of tryptase. J Pharmacol Exp Ther 1998, 286:289-297.

29. Damerau B, Lege L, Oldigs HD, Vogt W: Histamine release, formation of prostaglandin-like activity (SRS-C) and mast cell degranulation by the direct lytic factor (DLF) and phospholipase $\mathbf{A}_{2}$ of cobra venom. Naunyn Schmiedebergs Arch Pharmacol 1975, 287:141-156.

30. Moreno JJ, Ferrer X, Ortega E, Carganico G: PLA oedema in rat skin and histamine release in rat mast cells. Evidence for involvement of lysophospholipids in the mechanism of action. Agents Actions 1992, 36:58-63. 
31. Saito H, Matsumoto K, Okumura S, Kashiwakura J, Oboki K, Yokoi H, Kambe N, Ohta K, Okayama Y: Gene expression profiling of human mast cell subtypes: an in silico study. Allergol lnt 2006, 55:173-179.

32. Saban MR, Saban R, Bjorling D, Haak-Frendscho M: Involvement of leukotrienes, TNF-alpha, and the LFA-I/ICAM-I interaction in substance P-induced granulocyte infiltration. J Leukoc Biol 1997, 6I:445-45I.

33. Toru H, Kinashi T, Ra C, Nonoyama S, Yata J, Nakahata T: Interleukin-4 induces homotypic aggregation of human mast cells by promoting LFA-I/ICAM-I adhesion molecules. Blood 1997, 89:3296-3302.

34. Bradford MM: A rapid and sensitive method for the quantitation of microgram quantities of protein utilizing the principle of protein-dye binding. Anal Biochem 1976, 72:248-254.

35. Ishimaru K, Kihara $\mathrm{H}$, Ohno M: Purification and properties of phospholipase $A_{2}$ from venom of Trimeresurus flavoviridis (Habu snake). J Biochem 1980, 88:443-45I.

36. De Araújo AL, Radvanyi F, Bon C: Purification of an acidic phospholipase $A_{2}$ from Bothrops lanceolatus venom: molecular and enzymatic properties. Toxicon 1994, 32:1069-108I.

37. He S, Walls AF: Human mast cell tryptase: a stimulus of microvascular leakage and mast cell activation. Eur J Pharmacol I997, 328:89-97.

38. Di Rosa M, Giroud JP, Willoughby DA: Studies on the mediators of the acute inflammatory response induced in rats in different sites by carrageenan and turpentine. J Pathol 197I, 104:15-29.

39. Teather LA, Afonso VM, Wurtman RJ: Inhibition of platelet-activating factor receptors in hippocampal plasma membranes attenuates the inflammatory nociceptive response in rats. Brain Res 2006, 1097:230-233.

40. Southorn BG, Palmer RM: Inhibitors of phospholipase $\mathbf{A}_{2}$ block the stimulation of protein synthesis by insulin in L6 myoblasts. Biochem J 1990, 270:737-739.

41. Thomas CA, Yost FJ Jr, Snyderman R, Hatcher VB, Lazarus GS: Cellular serine proteinase induces chemotaxis by complement activation. Nature 1977, 269:521-522.

42. Fernandes CM, Zamuner SR, Zuliani JP, Rucavado A, Gutiérrez JM, Teixeira CF: Inflammatory effects of BaPI a metalloproteinase isolated from Bothrops asper. snake venom: leukocyte recruitment and release of cytokines. Toxicon 2006, 47:549-559.

43. Zamuner SR, Zuliani JP, Fernandes CM, Gutiérrez JM, Teixeira CF: Inflammation induced by Bothrops asper venom: release of proinflammatory cytokines and eicosanoids, and role of adhesion molecules in leukocyte infiltration. Toxicon 2005, 46:806-8I3.

44. Zuliani JP, Fernandes CM, Zamuner SR, Gutiérrez JM, Teixeira CF: Inflammatory events induced by Lys-49 and Asp-49 phospholipases $A_{2}$ isolated from Bothrops asper snake venom: role of catalytic activity. Toxicon 2005, 45:335-346.

45. Takahara A, Sugiyama A, Satoh $Y$, Hashimoto K: Comparison of four rate-correction algorithms for the ventricular repolarization period in assessing net effects of IKr blockers in dogs. J Pharmacol Sci 2006, 102:396-404.

46. Takahara A, Sugiyama A, Hashimoto K: Reduction of repolarization reserve by halothane anaesthesia sensitizes the guineapig heart for drug-induced QT interval prolongation. $\mathrm{Br} J$ Pharmacol 2005, 146:561-567.

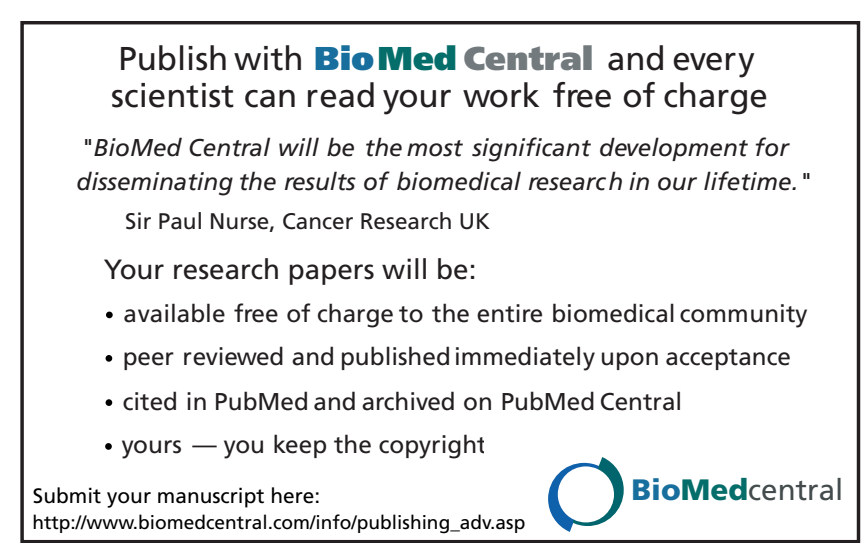

